\title{
THE 2005 LESOTHO \\ LOCAL GOVERNMENT ELECTIONS \\ Implications for Development and Governance
}

\author{
By \\ Victor Shale
}

Victor Shale is the Director of the Conflict Management Education

and Training Programme in Lesotho.

He has written and published papers in the area of

Conflict Management and Diplomacy.

P.O. Box 15020, Maseru 100 Lesotho

Tel: +26663070440 or +27734970252

e-mail: shalevictor@yahoo.co.uk

\begin{abstract}
In April 2005 Lesotho held its first democratic local government elections since attaining political independence from Britain in 1966. Thus, over the past four decades, the country has used various unelected interim structures to carry out development activities countrywide; structures which were not built on democratic foundations. Consequently there are, understandably, high expectations for the new local government structures put in place through the April election. The Ministry of Local Government, charged with the responsibility for implementing local government in Lesotho, worked jointly with the Independent Electoral Commission (IEC) to manage and administer the elections. Both worked in earnest to take care of the logistical arrangements throughout all the stages of the election: pre-election, polling and post-election. One component of the vigorous debate that marked the election revolved around the fact that a proportion of the electoral divisions was reserved for women only, with a view to enhancing gender equality in the decisionmaking and development processes. Controversial as it proved to be from a legal point of view, politically this is a progressive step that conforms with the purpose of developmental local government, which is that of service delivery through active participation by all sectors of the community. This paper looks at the Lesotho local government elections and their implications for development and governance. The paper expresses the view that elections are not an occasion but part of the process towards sustainable development and democratic consolidation. Elections are, therefore, not an end in themselves but a means to an end: that end being development and governance.
\end{abstract}




\section{INTRODUCTION}

The Kingdom of Lesotho conducted successful National Assembly Elections in 2002 that were declared free and fair by election observers from the Southern African Development Community (SADC) region and from further afield. Despite the fact that the Basotho National Party (BNP) lodged a case in the High Court disputing the outcome, the election results were generally well received by opposition parties, unlike the conflict-ridden 1998 elections, which, as Matlosa (2003, pp 8-9) puts it, almost precipitated a civil war. The violent conflict that followed the 1998 elections was arrested by diplomatic and military intervention from Lesotho's powerful neighbour, South Africa, assisted later by Botswana in what was dubbed a SADC intervention force. Following that violent election and its calamitous aftermath, Lesotho embarked upon a comprehensive electoral reform programme in advance of the 2002 elections. Thus, the success of the 2002 elections is attributable, in part, to the adoption of the Mixed Member Proportional Representation model (MMP) that has put Lesotho on the map as a pioneer and a good example of transparent and democratic elections in Africa as a whole and the Southern African region in particular.

The consequence of this new model was an increase in the number of seats in Parliament. This increase has resulted in greater costs to tax payers in this tiny mountain kingdom - a situation that has been defended by the Prime Minister of Lesotho in a statement in which he asserted that 'there is no cheap democracy'. The National Assembly now consists of 120 members. Eighty of them are elected through the first-past-the-post (FPTP) system and 40 through the Proportional Representation (PR) system (for more on the electoral model see Shale 2004). Following the National Assembly elections, the government and Lesotho's Independent Electoral Commission (IEC) shifted focus from the national elections to the local government elections.

Although the 2005 local government elections were Lesotho's first, there has been some form of local authority in place since independence and the role of these authorities cannot be jettisoned. The paper, therefore, begins with a historical perspective on decentralisation in Lesotho, starting with the colonial era and moving onto the post-colonial era, looking at the period immediately after independence (1966 to 1992) and the contemporary period (from 1993 to 2005). The paper also discusses the inclusion of women through the allocation to them of one-third of the seats in the new councils.

\section{The Colonial ERA}

Local government can be traced back to the colonial era, during which time it went through various stages. Both development and governance issues, including dispute resolution, were dealt with through the traditional courts and Lipitso (public gatherings) presided over by the chiefs. The people were therefore able to participate 
in the decision-making process so that they owned the decisions to a considerable degree. The system of Lipitso was, however, made unpopular by the colonial power, which turned it into a forum for making regulations and decisions that did not go down well with the majority of the people and, in fact, in most instances, went against the interests of the people. The colonial government later replaced the Lipitso system with the Basotho National Council (BNC), which was a consultative body. At this point the colonial administration existed side by side with the traditional rule of chieftaincy. According to Wallis (1999, p 93) the BNC established the District Councils (DCs) in an attempt to increase popular participation and promote its political acceptance by the people.

Following the 1959 Local Government Proclamation, certain powers were vested in the district councils, whose elected membership ranged from 15 to 28 people. As has been the case with the subsequent councils, chiefs were ex-officio members of the district councils. The councils did not have legislative or revenue raising powers and their role in delivery of services and the general development of their respective districts was limited. They had no autonomy in the recruitment or treatment of their own staff. This was done by the Local Government Service, which dealt with the appointment of staff, probation and confirmation, promotions and transfers, termination of the appointments and discipline as well as with the confidential reports of the employees (Local Government Orders 1965).

\section{The Post-Colonial Era}

Lesotho became independent in 1966 and after independence the Basotho National Party (BNP)-led government retained the local councils, albeit for a short time. The Local Administration Repeal Act was passed in 1969 and the district councils were abolished on political grounds as the ruling party deemed them undesirable. The main reason for this decision was the competition for power between the ruling party and the Basutoland Congress Party (BCP), whose domain was local government. Nine of the ten district councils were controlled by the $\mathrm{BCP}$ and Wallis (1999, p 93) suggests that this was a recipe enough for conflict. Cooperation between the central and the district councils was problematic so the only logical option for the BNP government was to abolish the councils as a strategy to thwart any attempt by the $\mathrm{BCP}$ to entrench itself at grass roots level. Local administration became the responsibility of the then Ministry of the Interior (now Ministry of Local Government).

In 1970 the Constitution was suspended and all political activity was banned in Lesotho following the elections which saw the BCP emerge as victors. Their victory was short lived because of discrepancies which resulted in the government nullifying the elections. There were, however, clear signals that the polity was eager to participate in governance. Development, which was entirely the responsibility of the central government, was proving a fiasco, and this led to the establishment of village development committees, later to be converted to village development 
councils, which are discussed below. The ban on political activity meant that the village development committees could not be democratically elected and were therefore not accepted by the communities as legitimate bodies. They were mainly seen as agents of the government and could not effectively deal with local development issues.

\section{Maseru City Council (MCC)}

After 1970 the political climate in Lesotho was far from conducive to the establishment of local authorities, at least until after 1993. The BNP government had, however, realised that there was a need for a body that would be responsible for the development of the urban areas. In 1983 the Urban Government Act of 1983 was passed to address this need. Because of inadequate financial and human resources, the Act only came into operation in 1989 after donor intervention.

Elections for the Maseru Municipality were conducted on several occasions, with candidates standing for election in 16 constituencies, but when the council's term of office came to an end in 2000 it was suspended because the government felt it was not effective and had become too expensive to sustain. Despite the fact that no development had taken place councillors were demanding an increase in their allowances. The powers of the Mayor of Maseru have since been vested in the office of the Chief Executive and Town Clerk. Under this arrangement, the Town Clerk is an employee of the council and does not account to the residents of Maseru but to the Minister of Local Government. It was anticipated that having the Town Clerk at the helm of the MCC would be a temporary arrangement because the local government elections were planned for the end of 2003 or early 2004.

\section{The Village Development Councils}

The village development councils (VDCs) replaced the village development committees after the enactment of the Village Development Orders of 1981 and of 1986. These were rural based councils consisting of seven elected members and one gazetted ${ }^{1}$ chief. During the period of military rule the VDCs were given a new mandate. The VDCs Order of 1991, which was subsequently amended in 1994 and 1995, provided that their functions would be as described in Table 1. Before the amendment, chiefs were ex-officio members and chairpersons of the councils.

By 2001 the tenure of office of all the village development councils had expired. At that point, most of them existed only in name because they had lost many members through migration and death and there was no mechanism for replacing the lost members. In addition, government had experienced problems with the

1 There are mainly two types of chiefs, namely gazetted and ungazetted. The former have their names published in a Government Gazette, receive monthly allowances and have decision-making powers in their area of jurisdiction. 
councils and the councils were in constant conflict with chiefs, who were opposed to the amendment of the law which had resulted in their removal as automatic chairpersons of the VDCs as they believed that this took away their powers to perform their duties and to rule (Shale 2004).

Table 1

VDCs and Their Functions

\begin{tabular}{|c|c|c|}
\hline VDC Membership & Establish Law & Functions \\
\hline $\begin{array}{l}7 \text { members } \\
1 \text { gazetted chief }\end{array}$ & $\begin{array}{l}\text { VDCs Order } 1991 \\
\text { (amended in 1992, } \\
1994 \text { and } 1995\end{array}$ & $\begin{array}{l}\text { Responsibility for } \\
\text { planning, formulation, } \\
\text { implementation and } \\
\text { maintenance of } \\
\text { development activities. } \\
\text { - Represent and guide the } \\
\text { local community and } \\
\text { identify community } \\
\text { needs. } \\
\text { - Raise funds for local } \\
\text { development. } \\
\text { Inform government of } \\
\text { local development } \\
\text { priorities. }\end{array}$ \\
\hline
\end{tabular}

\section{The URBAN BOARDS}

After the establishment of the VDCs throughout the country, there was a need to address the development imbalance between the rural areas and the district towns, other than Maseru, that had been created by the establishment of VDCs in the rural areas. In 2000, therefore, eleven urban boards were established under the Urban Government Act of 1983. The Ministry of Local Government demarcated the villages which fell under the urban areas into electoral divisions, from which nominees were to stand for election. The number of electoral divisions in each village ranged between ten and fifteen. Once this was done, the Minister of Local Government published in a Government Gazette his intention to declare the demarcated areas urban board areas. ${ }^{2}$ Written public representations were invited, the areas were declared urban board areas and candidates were elected (in elections facilitated by

2 These included the urban areas of Maputsoe and of Semonkong. The former surpasses some district towns in terms of economic activity even though it is not a district town, while the latter is a newly established urban area. 
the ministry's personnel) by means of a ballot within the specific electoral divisions. The winners became members of the urban boards. According to the Ministry of Local Government (2003, p 5), these boards, which were charged with planning, development control, and responsibility for public stand pipes, public toilets and markets, operated their own bank accounts.

\section{The InTERIm Community Councils}

In 2002 the Ministry of Local Government put into effect s 7 of the Local Government Act 1997 as a provisional move towards the establishment of fully-fledged local authorities. The Minister of Local Government left it up to the communities to nominate their own representatives. Two hundred interim community councils and ten district councils were nominated, a move disputed by opposition parties who questioned the legality of the minister's action because the councils were nominated and not elected. These community councils were the last of the interim structures that preceded the new democratically elected councils.

The nomination exercise was conducted through public gatherings at which communities were invited to nominate their candidates and then elect finalists / councillors through a ballot system. The process was not accepted by the opposition parties and non-governmental organisations, who felt it was a breach of the provisions of the law. Opposition parties claimed that in some places the nominations were conducted among the members of the ruling Lesotho Congress for Democracy (LCD) only. The Ministry of Local Government asserted that this was a free and fair exercise done transparently with the local people. The interim structures were formally endorsed in 2002 by the government, despite the fact that they enjoyed little or no legitimacy among those outside the ruling party. This action, more than any other, destroyed the confidence of opposition parties in the future process of establishing local government and subsequent elections.

\section{The 2005 Local GOVERnMent Elections AND THEIR IMPLICATIONS}

Elections in Lesotho are enshrined in s 20 of the Constitution, which provides that every person has the right to take part in the conduct of public affairs directly or through freely chosen representatives. The Constitution of Lesotho further provides for the establishment by Parliament of local government. This is clearly set out in s 106, which reads as follows:

Parliament shall establish such Local Authorities as it deems necessary to enable urban and rural communities to determine their affairs and to develop themselves. Such authorities shall perform such functions as may be conferred by an act of Parliament. 
The April 2005 local government elections have attracted a lot of attention from political analysts and academics, primarily because, despite the worldwide acclaim that greeted the 2002 elections where Mixed Member Proportional Representation system was used, the local government elections were conducted on a first-pastthe-post basis. FPTP is seen by some people as negative, given its win-lose character. The use of the FPTP in the local elections has also been seen as a negation of the achievements of the country with regard to elections. Some argue that if the MMP has proved to be a solution to the country's long history of political conflict and that this has been acknowledged worldwide, it is schizoid to discard it when it comes to local government elections.

The pluralist systems, according to Hartmann (2004, p 178), lead to a high percentage of uncontested elections. Opposition parties objected to the use of FPTP and called for the postponement of the elections to allow for further consultations. When this call went unheeded they gave their followers what Kekeletso (2005, p 2) calls an 'orange light' to participate in the elections. As a result, many people stood for the elections as independent candidates instead of as political party candidates. Most of the independent candidates fared well, signifying the birth of new era in which voters are beginning to have confidence in individuals instead of political parties. The absence of serious political party competition made it easy for candidates of the ruling Lesotho Congress for Democracy to win the elections unopposed in many electoral divisions.

A look at the developments leading up to the local elections, starting with the establishment of the interim structures, shows that there has always been a stalemate between the government and opposition parties. There is a growing pattern in which government decides what it wants to do, and, despite the objections of opposition political parties, goes ahead with its plans. In this development, government somehow succeeds in relegating opposition parties to a status of insignificance where the people see them as opposed to democracy and development - the argument surrounding the reservation of seats for women being a case in point. Opposition parties are no longer seen as potential partners who have something to share with the government; both the opposition and the government are apportioned the blame for lack of development in Lesotho because of their failure to transcend their political differences and concentrate on the needs of the communities.

Another important issue as far as the Lesotho local elections are concerned is that there are 128 community councils, consisting of 1272 councillors, as illustrated in Table $2 .^{3}$ The alarming rate at which people die of HIV / AIDS-related illnesses, as well as other factors like the rural-urban migration, means that the councils will lose members in large numbers. In fact, even before the councils begin to operate

3 Electoral divisions have been used as a basis for this figure. The assumption here is that there is a candidates for every electoral division. The figure, therefore, includes the electoral divisions which do not yet have councillors, as a result of failed elections and by-elections. 
there were failed elections because some nominees had died before election day ${ }^{4}$. The IEC now has to make preparations for further nominations and must conduct elections in these areas. It must also hold fresh elections in a number of areas where the election result was a tie. All these activities have serious financial implications for the IEC and the already fragile economy of the country and its over-stretched budget.

\section{Table 2}

\section{District and Community Councils}

\begin{tabular}{|l|c|c|}
\hline District Councils & No. of Community Councils & No. of Councillors \\
\hline Botha-Bothe & 10 & 96 \\
\hline Leribe & 18 & 178 \\
\hline Berea & 10 & 104 \\
\hline Maseru & 15 & 147 \\
\hline Mafeteng & 12 & 116 \\
\hline Mohale's Hoek & 14 & 140 \\
\hline Quthing & 10 & 105 \\
\hline Qacha's Nek & 11 & 103 \\
\hline Thaba-Tseka & 13 & 127 \\
\hline Mokhotlong & 15 & 156 \\
\hline Total & $\mathbf{1 2 8}$ & $\mathbf{1 2 7 2}$ \\
\hline
\end{tabular}

Another reason for the interest in the local elections is the amendment of the Local Government Act 1997 to include one-third representation of women in local government structures. In 1997, the SADC member states undertook to address gender inequality among public representatives. According to Letuka et al (2004, p 21) Lesotho reaffirmed its commitment by signing the SADC declaration, which requires the removal of all provisions in the laws of member states that discriminate against women. Another significant attribute of this declaration is the fact that the member states committed themselves to ensuring a minimum of 30 per cent representation of women in political leadership and decision-making by 2005 .

Section 4 of the Local Government Act, which deals with the composition of councils, has been amended to include a clause that lays down that no fewer than one-third of seats in a council shall be reserved for women. The Local Government

4 Another reason for the failure of an election can be that there is no turnout during nominations. Statistics on the failed elections were not yet available when this paper was written. 
Elections Act of 1998, which outlines the procedures, rules and regulations for the local government elections has also been amended to accommodate the election of women. The problem, however, is that neither Act specifies how the seats are to be reserved. Section 18(1A) of the Local Government Elections Amendment Act 2004 only provides that 'In accordance with the Local Government Act 1997, one third of the reserved seats in each Council shall be from every third electoral division'. The IEC has therefore adopted a multi-stakeholder strategy to determine the electoral divisions to be reserved for women.

Political parties were invited to take part in a random selection of the electoral divisions to be reserved. While this was done to legitimise the process, it did not cater for people who intended to contest elections as independent candidates because the political parties did not necessarily represent their interests in determining the electoral divisions.

Table 3

Electoral Divisions per District per Council

\begin{tabular}{|l|c|c|c|}
\hline District Councils & $\begin{array}{c}\text { No. of Community } \\
\text { Councils }\end{array}$ & $\begin{array}{c}\text { No. of electoral } \\
\text { divisions }\end{array}$ & $\begin{array}{c}\text { No. of reserved } \\
\text { electoral divisions }\end{array}$ \\
\hline Botha- Bothe & 10 & 96 & 30 \\
\hline Leribe & 18 & 178 & 54 \\
\hline Berea & 10 & 104 & 30 \\
\hline Maseru & 15 & 147 & 45 \\
\hline Mafeteng & 12 & 116 & 36 \\
\hline Mohales' Hoek & 14 & 140 & 42 \\
\hline Quthing & 10 & 105 & 31 \\
\hline Qacha's Nek & 11 & 103 & 33 \\
\hline Thaba- Tseka & 13 & 127 & 39 \\
\hline Mokhotlong & 15 & 156 & 385 \\
\hline Total & $\mathbf{1 2 8}$ & $\mathbf{1 2 7 2}$ & 45 \\
\hline
\end{tabular}

SOURCE: IndePENDENT Electoral COMMISSION

Table 3 shows that 385 women have been elected to serve the local government councils. This constitutes one-third of the 1272 councillors. After the nomination exercise a man from the Litjotjela Community Council area sued the government, saying his constitutional right to participate in the elections as per s 20 of the Constitution had been violated. His case was also based on s 18(3) of the Constitution, which states that no person shall be discriminated against because of 
race, sex, and so on. His legal team argued that women should be empowered but their empowerment should not be at the expense of other people's constitutional rights, such as the right to stand for election. The decision of the High Court was that the law seeks to empower women and that fact overrides the question of whether the manner in which women are empowered is constitutional or not. The man's claims were therefore dismissed.

Lesotho should be commended for this bold step ensuring the participation of women despite many cacophonous utterances, particularly from conservative male folk around the country. The greatest challenge, though, is for the government to ensure that despite the absence of support from some politicians, the councils become credible institutions that can bring about development change in Lesotho. Reserving seats for women is not a new phenomenon. It has been done by other developing countries, like India. However, given the fact that India is a caste society, it may be expected that the problems likely to arise in Lesotho from this reservation of seats will be comparatively fewer than those that emerged in India. According to Poornima and Vinod Vyasulu $(1999$, p 1) India passed laws that made it obligatory for local governments to include women. One-third of seats in local bodies such as village councils (which are also called grams), municipalities, city corporations and districts are reserved for women and here women compete only against other women. The UNDP observes that the Indian experience is that most of the women become surrogates for their husbands, who are unable to contest elections because of the reservation.

A final reason for the interest generated by the elections is the general scepticism of the people about local government. People doubt that the newly elected local authorities will be any more effective than their predecessors (the interim community councils and the village development councils), which were never given the power to perform the functions they were expected to perform. These councils were also not accountable to the people and this undermined democratic governance. Statistics from the IEC regarding the elections indicate that there was a 30,22 per cent voter turnout in the entire country. In one electoral division, only 23 voters of a potential 2053 (about 1,12\%) voted.

The disappointing turnout has implications for development in terms of the likely lack of support for the councils. The councillors who have not been elected by the majority of the electorate face the daunting task of winning the support of the electorate after the elections. This is complicated by the fact that some members of the ruling party who were hoping to stand for election were disillusioned when the party chose different candidates. In some areas the nominated candidates were not accepted by the locals, resulting in some members standing as independent candidates against their party's candidates.

Table 4 illustrates this point with a look at eight major political parties and their performance against independent candidates. In Mokhotlong District independent candidates won 64 of 149 electoral divisions. This is very close to the 67 divisions won by the ruling party. 
This indicates a loss of grip by the ruling party, which, in the 2002 National Assembly elections, won 79 of 80 national constituencies. The Mokhotlong District results are interesting to analyse because of the current tug-of-war between the LCD Member of Parliament and the party. The MP had been suspended by the party after apparently speaking out openly against senior party officials and some ministers who he accused of misusing resources. While this matter is still sub judice, the developments on the ground together with the election result suggest that the people in this district are prepared to cross swords with the ruling party. It remains to be seen whether the action that was taken against the MP for his alleged defiance will apply mutatis mutandis to those councillors who have defied the party by contesting elections as independent candidates. As was the case with the interim structures prior to the elections, the newly elected councils whose candidates have been imposed will indeed experience rejection by some of the people.

Table 4

Electoral Division Results per District per Political Party

\begin{tabular}{|l|c|r|r|r|r|r|r|c|}
\hline District & $\begin{array}{c}\text { Independent } \\
\text { Candidates }\end{array}$ & LCD & BNP & PFD & NNP & BAC & LPC & BCP \\
\hline Maseru & 24 & 112 & 1 & 2 & 1 & - & - & - \\
\hline B.Bothe & 24 & 70 & - & - & - & - & 2 & - \\
\hline Leribe & 29 & 135 & 7 & 2 & - & 1 & 1 & - \\
\hline Berea & 10 & 76 & 2 & 1 & - & 1 & 12 & - \\
\hline Mafeteng & 22 & 91 & 2 & 1 & - & - & - & - \\
\hline M.Hoek & 26 & 109 & 2 & - & - & - & 1 & 1 \\
\hline Quthing & 20 & 81 & 1 & - & - & - & 1 & - \\
\hline Qacha'sNek & 9 & 91 & 1 & - & - & - & - & - \\
\hline Mokhotlong & 64 & 67 & 14 & - & - & - & 2 & 1 \\
\hline Thaba-Tseka & 23 & 101 & 10 & 1 & - & - & - & - \\
\hline
\end{tabular}

SOURCE: IEC EleCtion ResUlts 2005

Table 4 shows that, apart from the Mokhotlong District, in almost all the districts independent candidates did well against political parties. This contrasts with the situation in the general elections, when political parties won more votes than independent candidates. Another conclusion to be drawn from Table 4 is that the LCD dominated the local government elections as it did the general elections.

The low level of participation in the elections is attributable to a number of factors. The elections were held on a Saturday, when many people had either gone to work as this was a normal working day or were busy burying their loved ones. 
It is apparent that there was little pre-preparation for the elections in terms of voter and civic education and the pre-election phase did not conform with the fundamental principles of good governance because it was full of controversy.

It is, however, fair to acknowledge the role played by civil society groups, despite the alleged absence of cooperation from the government. The lack of cooperation is ironic given the growing importance globally of civil society and non-governmental organisations (NGOs) in development. Kabemba (2003, p 37) notes that, whether deliberately or by design, the exclusion of civil society results in development being a distant mirage. Despite the fact that civil society in Lesotho is not very strong, the Lesotho Council of Non-Governmental Organisations (LCN) and the Transformation Resource Centre (TRC) have been visibly involved in informing communities about the local government elections.

Inadequate time for election preparation was another issue of dissatisfaction among opposition political parties. They also pointed out that there were many loopholes in the legislation. Technical errors, such as the nomination form not providing for the party sponsorship of the candidate, were another concern. The parties claimed that the voters' rolls were not widely distributed to the community and the parties, hence their call for the postponement of the elections. The low voter turnout vindicates some of their claims.

\section{Table 5}

\section{Ministry of Local Government Functions to be Decentralised}

Preparation, implementation and administration of plans, including plans for the expansion of settlements and minimising settlement encroachment on agricultural land

1. Land allocation

2. Building control

3. Enforcement of conditions attached to land and site allocations

4. Undertaking and management of the process of land adjudication

5. Preparation of local, part and sector plans in respective areas of jurisdiction

6. Land use planning (for an area)

7. Management of land held for community use (eg, open spaces)

8. Control and regulation of markets and bus terminuses

9. Stray stock management, including takeover/management of pounds for stray cattle and collection of fines

10. Bewys ${ }^{5}$ writing

11. Registration of births and deaths

12. Administration of estates

13. Gazetting of chiefs

14. Community development

15. Burials of the destitute

16. Dealing with deportees

SOURCE: InTER-Ministerial TASK ForCe MAY 2004

5 Bewys is an Afrikaans word used in Lesotho to refer to the official document used for registering livestock. 
It is necessary, therefore, to look closely at the implications of the elections in terms of the limitations on and possibilities of the councils performing the functions assigned to them and in relation to the roles of women and of chiefs. By implication, the local authorities will be able to perform their designated functions if the legislation under which these functions are to be performed is amended. At present it is difficult for them to perform those functions effectively because most of the laws governing them conflict with one another and, in particular, with the Local Government Act. All line ministries have identified the functions that will be transferred to the local authorities after the elections. For instance, the Ministry of Local Government has identified the functions listed in Table 5, which, as would be expected, have implications for other sectors as well. For instance, one function under this ministry, the control and regulation of markets and bus terminals, also involves the Ministry of Health and Social Welfare, which oversees the health standards at these places. This function, therefore, has to be performed in liaison with the relevant government ministry or ministries.

\section{The Role of Women in Local Governance}

It is difficult to avoid the temptation to talk about women's involvement in local government elections and development generally, without touching on its implications for their traditional role. Any discussion about their participation should consider a larger picture which takes cognisance of their general social responsibilities such as the increasing responsibility to nurse the sick and care for children who have been orphaned by the HIV / AIDS pandemic. The United Nations Children's Fund (UNICEF 1990), in declaring the rights of the child, has maintained that strengthening the role of women in general and ensuring their equal rights will be an advantage to the children. The escalation of HIV / AIDS means that there has to be an appreciation of the fact that in addition to an expectation that they will participate in local government, many women have now added an extra burden to their already demanding role in the household.

Women's participation in local politics will simply be added to their normal social and economic burden. Advocates of women's participation should not have high expectations that women, through their presence in the councils, will make an instant impact on development. They must acknowledge that these women, being the cornerstones of their households, will have a tough time because they will have to choose between attending council meetings and playing their traditional role as homemakers and caregivers. In the circumstances it is possible that their decisions to attend will not be based as much on the needs of the council as on their sense of duty in relation to their homes. It is important, therefore, that they are not pressurised to perform in councils according to expectations but are given time to adjust and are helped by the necessary technical and administrative support. This will go a long way towards making the councils sustainable.

It is also important to note that the majority of women who contested Lesotho's 
local government elections are based in rural areas, yet they have higher literacy levels than their male counterparts. Despite this reality, many of them still depend on their husbands for the money to provide for their families. They are also expected to obtain permission from their husbands to be involved in the many voluntary activities for which they are renowned. Unlike their male counterparts, women do not have assets because the provisions of laws such as the Deeds Registry Act of 1967 still discriminate against them.

For instance, s 14(3) of the Deeds Registry Act provides that:

The bonds or other rights shall not be transferred or ceded to, or registered in the name of, a woman married in community of property, save where such property, bonds or other rights are by law or by a condition of a bequest or donation excluded from the community.

Sub-section (6) of the same section states that the registrar shall:

... refuse except under an order of court to attest, execute or register all deeds and documents in respect of immovable property in favour of a married woman whose rights are governed by Basuto Law and custom where such registration would be in conflict with Basuto law and custom shall not be made in the name of women.

This means that in facilitating the registration of property, women councillors will be perpetuating discrimination against women, which, in turn, hinders them from participating effectively in development. The fact that one-third of the seats have been reserved for women does not automatically mean that they are empowered. The laws that discriminate against them prevent them from participating effectively in development. Given their active role in the establishment and sustenance of societies in pursuance of development, their energy has to be tapped for the good of the councils.

\section{Participation of Chiefs in Governance}

The Local Government Elections Act does not address the question of chiefs' participation in the elections. The process of determining the chiefs who will participate in local government councils was decided and facilitated by the Ministry of Local Government. Chiefs did not stand for election but, in terms of s 4 of the Local Government Act 1997, were nominated by other chiefs, who convened in a given council area. According to Wallis (1999, p 101) some chiefs have, in the past, been opposed to local government, maintaining that it is a weapon intended to break their power. Indeed, chiefs have posed problems for the development councils in the past, particularly after they were stripped of the ex-officio membership which had made them chairpersons of the local councils. According to the current interim 
arrangements chiefs are members of the councils but are not automatic chairpersons - a situation that does not go down well with many of them. If the chiefs feel compromised, governance in their respective areas may be crippled. I have stated elsewhere that it is axiomatic that even if they do not openly obstruct the activities of the local government councils, the chiefs have the ability to use their residual power to influence the community to rise against the councillors.

There is a great deal of work to be done to get the newly elected structures operational. For instance, government must still develop regulations that will be used to administer the designated functions of the councils. Equally important is the development of the fiscal decentralisation framework which is the sacrosanct pillar of the successful implementation of decentralisation.

Despite these challenges, Lesotho has taken a step in the right direction in terms of deepening democracy, demonstrated here by the holding of free elections. It is important for the government to consider holding the local government elections and the national elections simultaneously. This will not only minimise the costs but will ensure a comparatively better turnout of the electorate, given the importance attached to National Assembly elections.

\section{CONCLUSION}

There is no denying that Lesotho's road to democratic governance has been a bumpy one. This paper has indicated that as early as the 1960s there was a general problem pertaining to the acceptance of the legitimacy of the structures that were meant to spearhead development. Starting with the district councils, the village development councils and, lately, the interim community councils, there has been a pattern whereby these structures have never really been embraced by the communities. It comes as no surprise that even these newly elected councils were preceded by controversy.

The recent local government elections are not a panacea for development challenges in Lesotho but form part of the process leading to the amelioration of these challenges and the entrenchment of democracy. Local government is the centre of democracy because it is when people are able to run their own affairs that we can refer to a society as democratic. If the election process is to be successful there must be a comprehensive training programme for communities and the local government staff. As in national elections governments are born, local elections give birth to councils. It follows therefore that the newly elected councils that have been ushered in by the recent elections have been provided with an opportunity to tackle development problems.

The election results indicate that there was voter apathy. The big challenge is, therefore, to ensure the participation of all stakeholders, particularly more women, in future elections. The involvement of women in local government is not an end in itself, it is necessary if local government is to be imbued with a developmental conscience. It would otherwise be erroneous to claim to be consolidating democracy 
when some sectors of the population are discriminated against. It is fitting, therefore, to conclude that there is a dire need to promote ownership of the electoral process by all sectors of the community in order to have democratic governance. There is no democracy if it is not inclusive. Developments leading up to the local government elections and the subsequent results indicate without doubt that inclusive democracy, which should have been the result of the elections, has been compromised.

\section{- REFERENCES -}

Goering, L. 2004. 'Lesotho Women Hope for Control of their Lives: ravages of AIDS, high unemployment bolster case for legal end to men's deep-rooted dominance'. Chicago Tribune

Government of Lesotho. 1965. Local Government Orders 1965. Maseru: Government Printer

— 1967. Deeds Registry Act 1967. Maseru: Government Printer

—. 1979 Land Act 1979. Maseru: Government Printer.

—. 1993. The Constitution of Lesotho. Maseru: Government Printer

—. 1997. Local Government Act No.6 1997. Maseru: Government Printer

- 1998. Local Government Elections Act 1998. Maseru: Government Printer

- 2004. Local Government (Amendment) Act 2004. Maseru: Government Printer

—. 2004. Local Government Elections (Amendment) Act 2004. Maseru: Government Printer

Hartmann, C. 2004. 'Local Elections in the SADC Countries: A Comparative Analysis of Local Electoral Institutions'. Journal of African Elections 3(1).

Inter-Ministerial Task Force. 2004. A Report on the Proposed Functions for Local Authorities Over The Period 2004-9. Unpublished.

Kabemba, C (ed). 2003. From Military Rule to Multiparty Democracy: Political reforms and Challenges in Lesotho. Johannesburg: Electoral Institute of Southern Africa.

Kekeletso, M. 2005. 'Basotho Let Elections Pass them By'. Public Eye Newspaper 6 May.

Letuka P, K Matashane-Marite and M Mapetla. 2004. 'Gender And Elections in Lesotho: Perspectives on the 2002 Elections'. EISA Research Report No. 4. Johannesburg: Electoral Institute of Southern Africa.

Matlosa, K. 2003. Electoral System Reform, Democracy and Stability in the SADC Region: A Comparative Analysis. Johannesburg: Electoral Institute of Southern Africa.

Ministry of Local Government 2003 Status Report on the establishment of Urban Boards. Unpublished.

Poornima, R and V Vyasulu. 1999. 'Women in Panchayati Raj: Grassroots democracy in India, Experiences from Malgudi'. Paper presented at the workshop on 'Women and Political Participation: $21^{\text {st }}$ Century Challenges' 24-26 March. New Delhi.

Sephomolo, L. 2003. 'The Role of Women in Development and Politics in Lesotho'. Unpublished paper presented at the SADC Conference, Namibia. 
Shale, V R. 2004. Decentralisation, Development and Conflict: The Challenges Awaiting Local Authorities in Lesotho. Johannesburg: Electoral Institute of Southern Africa.

—. 2005. Demarcating Local Authority Boundaries for good Governance versus the People-to-People Relations: A Case Study of Lesotho. Johannesburg: Electoral Institute of Southern Africa.

UNICEF. 1990. First Call For Children: World Declaration and Plan of Action From The World Summit for Children. New York: United Nations.

Wallis, M. 1999. 'Lesotho: Seeking Local Democracy in the Mountain Kingdom'. In Reddy, PS (ed). Local Government Democratisation and Decentralisation: A Review of the Southern African Region. Cape Town: Juta \& Co Ltd. 